\title{
Molecular Evidence for Progenitorial Species of Garden Petunias Using Polymerase Chain Reaction-Restriction Fragment Length Polymorphism Analysis of the Chs-j Gene
}

\author{
Xinwang Zhang ${ }^{1}$, Ikuo Nakamura, and Masahiro Mii \\ Graduate School of Horticulture, Chiba University, 648 Matsudo, Matsudo \\ City, Chiba 271-8510, Japan
}

Additional index words. wild species, cultivar, classification, molecular marker

\begin{abstract}
Wild species and cultivars of Petunia were subjected to analysis for clarifying the historical progenitors of garden petunias (Petunia hybrida) using polymerase chain reaction-restriction fragment length polymorphism (PCR-RFLP) of Chalcone synthase $J(C h s-J)$ gene. The PCR products for $C h s-J$ intron with adjacent part of exons digested with $R$ saI enzyme revealed that $P$. integrifolia and $P$. inflata $(P$. integrifolia complex), both with purple flowers, had one large-sized band [650 base pairs (bp)], whereas $P$. axillaris ( $P$. axillaris complex), a white-flowered species, showed two smaller-sized bands (200 or $280 \mathrm{bp}$ and $350 \mathrm{bp}$ ). In $P$. axillaris, two different band patterns were found among the three subspecies: 200 and 350 bp for $P$. axillaris subsp. axillaris and 280 and 350 bp for $P$. axillaris subsp. parodii and subsp. subandina. The 200-bp band was revealed to be specific to $P$. axillaris subsp. axillaris. $P$. hybrida cultivars showed four different band patterns, each of which consisted of two to three of the four bands $(200,280,350$, and $650 \mathrm{bp})$ detected in the wild taxa examined. These results indicate that the wild species analyzed here might partially have contributed to the $C h s-J$ gene of garden petunias analyzed and demonstrate the use of PCR-RFLP in establishing relationships among closely related species and cultivars of Petunia. The puzzling problem related to the possible contribution of more than one subspecies of $P$. axillaris is discussed.
\end{abstract}

The cultivars of Petunia hybrida Vilm. (hereafter referred to as garden petunias) have been bred since the early 1830s (Paxton, 1836). The progenitors of garden petunias have been presumed to be $P$. axillaris $[=P$. axillaris (Lam.) Britton, Sterns \& Poggenb. subsp. axillaris, after current treatment] with white flowers and $P$. violacea Lindl. $[=P$. integrifolia (HOOK.) Schiz \& Thell.] with purple flowers (Ferguson and Ottley, 1932). Petunia inflata R. E. Fr with purple flowers and $P$. parodii Steere $[=P$. axillaris subsp. parodii (Steere) Cabrera ] with white flowers have also been proposed as a likely parent of garden petunias (Sink, 1975). Thus, it was a common idea that the garden petunias have been bred through cross-hybridizations between the $P$. axillaris complex and $P$. integrifolia complex. Recent detailed studies on wild Petunia species revealed that the $P$.

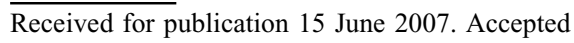
for publication 29 Aug. 2007.

We thank Drs. T. Ando and H. Kokubun, Graduate School of Horticulture, Chiba University, for providing original plant materials and helpful discussion. X. Zhang also thanks Dr. M. Kikuchi for his encouragement throughout conducting this study.

${ }^{1}$ To whom reprint requests should be addressed; e-mail miim@faculty.chiba-u.jp
}

axillaris complex consists of three subspecies, i.e., subsp. axillaris, subsp. parodii, and subsp. subandina T. Ando (Ando, 1996). These three subspecies are morphologically similar to each other except for flower characters, and it is difficult to identify which subspecies of $P$. axillaris has been used for the initial breeding of garden petunias. Moreover, another fundamental question still remains on the parental species used as a partner of $P$. axillaris complex because of the existence of several species closely related to $P$. integrifolia (Griesbach et al., 2000; Koes et al., 1987; Sink, 1975; Wijsman, 1982).

At present, comparison or analysis of sequences in fragments of organelle DNA amplified with the use of universal primers is widely used in species identification, genetic diversity, and phylogenetic studies in many plant species. Several attempts have been made to understand the phylogeny of Petunia sensu Jussieu using molecular data obtained by various methods of DNA analysis such as restriction fragment length polymorphism (RFLP) analysis of ribosomal DNA (Kabbaj et al., 1995), DNA amplification fingerprinting (Cerny et al., 1996), and RFLP analysis of chloroplast DNA (Ando et al., 2005a). As an alternative, polymerase chain reactionrestriction fragment length polymorphism
(PCR-RFLP) analysis, which is simple, rapid, reliable, and cost saving, has also been used as a powerful tool for identifying plant varieties and species in many plant species such as those in the genus Gossypium (Martsinkovskya et al., 1996), Beta (Shen et al., 1998), and Glycine (Xu et al., 2001). To our knowledge, however, PCR-RFLP analysis has not been used for determining the parents of garden petunias.

Chalcone synthase is a key enzyme of the anthocyanin biosynthesis and encoded by the structural Chs gene (Heller and Hahlbrock, 1980). In the inbred line of Petunia hybrida 'Violet 30', the Chs genes form a small multigene family consisting of $12 \mathrm{Chs}$ members, among which eight complete genes (Chs-A, B, D, F, G, H, J, and $L$ ) have been cloned (Koes et al., 1987, 1989a). Each complete Chs gene consisted of two exons separated by an intron of variable sequence (Koes et al., 1989a) and only two (Chs-A and $(\mathrm{Ch}-J$ ) were expressed mainly in floral tissues (Koes et al., 1989b). Based on these studies, Griesbach et al. (2000) analyzed the $C h s-A$ gene intron in some wild species and cultivars of Petunia and found that some genetic heterogeneity existed in wild species but not in garden petunias.

In this study, we applied PCR-RFLP analysis to the intron with adjacent part of exons in the Chs-J gene of several Petunia taxa and garden petunias for discriminating two taxonomic groups used as progenitors of garden petunias and for identifying the subspecies of $P$. axillaris that played a role as one of the progenitors of garden petunias.

\section{Materials and Methods}

Plant material. Seeds of five wild Petunia taxa, which were geographically isolated from each other, were collected from the known wild localities and of seven cultivars of garden petunias were obtained from several seed companies (Table 1). Among the wild taxa used, Petunia axillaris subsp. axillaris, $P$. axillaris subsp. parodii, and $P$. axillaris subsp. subandina had white flowers and $P$. integrifolia and $P$. inflata had purple flowers. These are the most probable progenitors of garden petunias. The seven cultivars of garden petunias chosen for the study differed in flower color, flower type, and introductory series. Plants were raised from seeds and grown in a greenhouse following standard practices for garden petunias. For the following DNA analysis, five plants were used for each wild taxon and garden petunia cultivar. In the wild taxa, the plants derived from one locality were used. All of these plant materials were confirmed to be diploid by flow cytometric analysis.

Genomic DNA isolation and polymerase chain reaction amplification. Total genomic DNA was extracted from $\approx 0.5 \mathrm{~g}$ of young leaves following a modified CTAB method (Lassner et al., 1989) and used for amplifying the region containing $C h s-J$ intron and adjacent partial exons by PCR. The forward primer sequence $\left(5^{\prime}\right.$-acagtgagcataagactgagct- $\left.3^{\prime}\right)$, 
Table 1. Voucher specimens of Petunia taxa and Petunia hybrida cultivars used in this study, the localities and herbaria holding them, or the sources.

P. axillaris (Lam.) Britton, Sterns \& Poggenb. (=P. nyctaginiflora Juss.) subsp. axillaris. Argentina: Buenos Aires, A292.

P. axillaris subsp. parodii (Steere) Cabrera. Uruguay: Artigas, U27.

P. axillaris subsp. subandina T. Ando. Argentina: Salta, A100.

P. intergrifolia (Hook.) Schinz \& Thell. (=P. violacea Lindl.). Uruguay: Río Negro, U106.

P. inflata R.E.Fr. Argentina: Misiones, A7.

P. hybrida 'PrimeTime White'. Goldsmith Seeds Inc.

P. hybrida 'Madness Pink'. Pan American Seed Co., Ltd.

P. hybrida 'Madness Orchid'. Pan American Co., Ltd.

P. hybrida 'Carpet Blue Lace'. Pan American Co., Ltd.

P. hybrida 'Carpet Lilac'. Pan American Seed Co., Ltd.

P. hybrida 'Baccara Salmon'. Sakata Seed Co., Ltd.

P. hybrida 'Flash Blue Vein'. Novartis Co., Ltd.

designated as CHSJ-F9, and the reverse primer sequence $\quad\left(5^{\prime}\right.$-aagaagcttagtgagctggtag- $\left.3^{\prime}\right)$, designated as CHSJ-R5, were selected from the exon I and exon II regions of Chs-J, respectively (GenBank accession X14597) (Fig. 1).

The PCRs were performed in PTC-100 Programmable Thermal Controller (MJ Research, Waltham, MA). The reaction mixture of $100 \mu \mathrm{L}$ contained $1 \mu \mathrm{L}$ genomic DNA solution, $1 \mu \mathrm{L}$ Taq DNA polymerase (Takara Co., Otsu, Japan), $10 \mu \mathrm{L}$ of $10 \times$ buffer $(500$ $\mathrm{mm} \mathrm{KCl}$ and $150 \mathrm{~mm}$ Tris, $\mathrm{pH} 8.0), 8 \mu \mathrm{L}$ mixed dNTP, $5 \mu \mathrm{L}$ of $20 \mu \mathrm{M}$ CHSJ-F9 and CHSJ-R5 primers, and $70 \mu \mathrm{L}$ of DW. Each reaction was performed by preheating at 95 ${ }^{\circ} \mathrm{C}$ for $8 \mathrm{~min}$. After $3 \mathrm{~min}$ incubation at $94{ }^{\circ} \mathrm{C}$ and 32 cycles of $95{ }^{\circ} \mathrm{C}$ for $45 \mathrm{~s}, 62^{\circ} \mathrm{C}$ for 1 $\mathrm{min}$, and $72{ }^{\circ} \mathrm{C}$ for $2 \mathrm{~min}$, the reaction was ended with $72{ }^{\circ} \mathrm{C}$ for 10 -min incubation and held at $4{ }^{\circ} \mathrm{C}$.

Polymerase chain reaction-restriction fragment length polymorphism analysis. The PCR products were then digested with restriction enzyme RsaI (New England BioLabs, Ipswich, MA) at $37{ }^{\circ} \mathrm{C}$ for at least $5 \mathrm{~h}$. The restriction mixture $(200 \mu \mathrm{L})$ consisted of $20 \mu \mathrm{L}$ PCR products, $160 \mu \mathrm{L}$ DW, $20 \mu \mathrm{L} 10 \times$ buffer, and 10 units RsaI. The PCR products and restriction fragments were then subjected to gel electrophoresis $(135 \mathrm{~V}$ constant voltage) in 1\% AmpliSize agarose (BioRad, Hercules, CA) for $25 \mathrm{~min}$ and 4\% AmpliSize agarose for $40 \mathrm{~min}$, respectively, in TAE with $0.5 \mu \mathrm{g} \cdot \mathrm{mL}^{-1}$ ethidium bromide.
DNA bands were photographed under ultraviolet light. Because small fragments obtained by RsaI digestion were difficult to determine accurately, they were excluded from the analysis.

\section{Results and Discussion}

Polymerase chain reaction products. The lengths of the intron in Chs- $A, B, D, F, G, H$, and $J$ of Petunia were previously reported as 1346, 3776, 694, 563, 2438, 406, and 728 base pairs (bp), respectively (Griesbach et al., 2000; Koes et al., 1989a). Although the primers for PCR analysis used in the present study were designed to amplify the intron plus an additional 309-bp exon of the Chs- $J$ gene, more than one of the Chs genes were expected to be amplified because of the small difference in the sequences of primer positions among the $C h s-A, B, D, F, G$, and $J$ (Table 2). However, in all the species analyzed, only a single PCR product (1040 bp), which fit the expected size of Chs-J (GenBank accession X14597), was obtained (Fig. 2A).

Polymerase chain reaction-restriction fragment length polymorphism analysis. We then tried to find out the PCR-RFLP markers by digesting amplified $C h s-J$ regions with several restriction enzymes (e.g., EcoRII, EcoRV, HaeIII, MspI, RsaI, SpeI, TaqI) to discriminate the uniform PCR products; only digesting with $R s a$ I distinctly gave the special restriction patterns among different

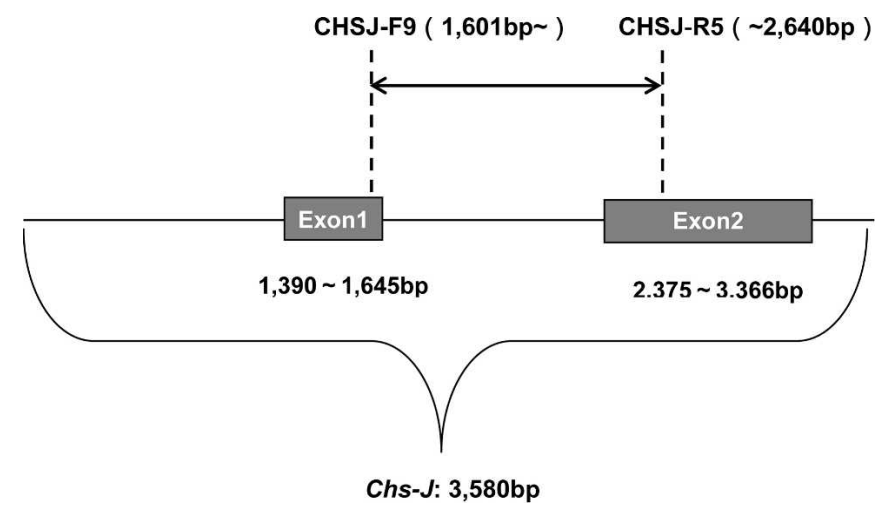

Fig. 1. The structure of the $C h s-J$ gene ( 3580 bp in length). Exons are shown as black blocks (Exon I, 1390 bp to $1645 \mathrm{bp}$; Exon II, $2375 \mathrm{bp}$ to $3521 \mathrm{bp}$ ). The bidirectional arrow denotes the target region amplified by polymerase chain reaction (forward primer CHSJ-F9 starts from $1601 \mathrm{bp}$; reverse primer sequence CHSJ-R5 starts from $2640 \mathrm{bp}$ ). genotypes. Three patterns of restriction fragments were detected in five Petunia taxa analyzed (Fig. 2B). Petunia integrifolia and $P$. inflata were identical in the restriction pattern exhibiting three fragments $(650,170$, and $130 \mathrm{bp}$ ), that was designated as type I. All three subspecies of $P$. axillaris showed four fragments but with two different banding patterns. Petunia axillaris subsp. parodii and subsp. subandina were identical in the restriction pattern $(350,280,170$, and 130 $\mathrm{bp})$, designated as type $\mathrm{P}$, but different from that of subsp. axillaris $(350,200,170$, and $130 \mathrm{bp}$ ), which was designated as type A. These results indicate that the sequences of amplified regions of $C h s-J$ are distinguishable between the $P$. integrifolia complex and $P$. axillaris complex by $R s a \mathrm{I}$.

The native taxa of Petunia are classified into four groups (A, B, C, and D) according to their constituents and contents of major anthocyanins and their difference in pigment biosynthesis patterns with respect to the presence of blocking mechanisms or inhibitors for the hydroxylation, glucosylation, and acylation reactions. The three subspecies of $P$. axillaris are classified into A group and $P$. integrifolia and $P$. inflata into D group, respectively (Ando et al., 1999). The results of the present study showed that a large disparity also exists between A group and D group with respect to the $C h s-J$ gene. Moreover, the $200 \mathrm{bp} R s a \mathrm{I}$ digested band of the amplified region was revealed to be specific to $P$. axillaris subsp. axillaris. Because three subspecies of $P$. axillaris could not be distinguished morphologically from each other before flowering (Ando, 1996), the $200 \mathrm{bp}$ RsaI band could be used as an efficient species-specific DNA maker to distinguish subsp. axillaris from the other two subspecies even at the early stage of seedling growth.

In seven garden petunia cultivars examined, four patterns were detected in the $R s a \mathrm{I}$ restriction fragments: type $\mathrm{P}$ with four fragments $(350,280,170$, and $130 \mathrm{bp})$ represented by 'Prime Time White' and 'Madness Pink'; type A with four fragments (350, 200, 170 , and $130 \mathrm{bp}$ ) represented by 'Flash Blue Vein' and 'Carpet Blue Lace'; type I+P with five fragments $(650,350,280,170$, and $130 \mathrm{bp}$ ) represented by 'Carpet Lilac' and 'Baccara Salmon'; and type A+P with five fragments $(350,280,200,170$, and $130 \mathrm{bp})$ represented by 'Madness Orchid' (Fig. 2B). The 200 bp RsaI restriction fragment of amplified regions of $C h s-J$, the specific marker for $P$. axillaris subsp. axillaris, was detected in some garden petunias such as 'Flash Blue Vein', 'Carpet Blue Lace', and 'Madness Orchid'. These results clearly indicate the existence of the polymorphism of $C h s-J$ intron in cultivars of garden petunias as well as wild Petunia species.

Progenitors of garden petunias. Variation in size of PCR products of Chs- $J$ was not detected (Fig. 2A), but a different pattern of $R s a$ I restriction fragments of PCR products was observed in garden petunias and Petunia taxa analyzed (Fig. 2B). Coexistence of 350and 200-bp fragments specific to $P$. axillaris 
Table 2. Sequence of the primers (CHSJ-F9 and CHSJ-R5) used in the present study to amplify the Chs- $J$ gene intron and the corresponding sequence in the other $C h s$ genes. $^{2}$

\begin{tabular}{lcccccccccccccccccccccc}
\hline$C H S J-F 9$ & $\mathrm{~A}$ & $\mathrm{C}$ & $\mathrm{A}$ & $\mathrm{G}$ & $\mathrm{T}$ & $\mathrm{G}$ & $\mathrm{A}$ & $\mathrm{G}$ & $\mathrm{C}$ & $\mathrm{A}$ & $\mathrm{T}$ & $\mathrm{A}$ & $\mathrm{A}$ & $\mathrm{G}$ & $\mathrm{A}$ & $\mathrm{C}$ & $\mathrm{T}$ & $\mathrm{G}$ & $\mathrm{A}$ & $\mathrm{G}$ & $\mathrm{C}$ & $\mathrm{T}$ \\
$C h s-J$ & $\bullet$ & $\bullet$ & $\bullet$ & $\bullet$ & $\bullet$ & $\bullet$ & $\bullet$ & $\bullet$ & $\bullet$ & $\bullet$ & $\bullet$ & $\bullet$ & $\bullet$ & $\bullet$ & $\bullet$ & $\bullet$ & $\bullet$ & $\bullet$ & $\bullet$ & $\bullet$ & $\bullet$ & $\bullet$ \\
$C h s-A$ & $\bullet$ & $\bullet$ & $\bullet$ & $\bullet$ & $\bullet$ & $\bullet$ & $\bullet$ & $\bullet$ & $\bullet$ & $\bullet$ & $\mathrm{C}$ & $\bullet$ & $\bullet$ & $\bullet$ & $\bullet$ & $\bullet$ & $\bullet$ & $\bullet$ & $\bullet$ & $\mathrm{T}$ & $\bullet$ & $\bullet$ \\
$C h s-B$ & $\bullet$ & $\mathrm{T}$ & $\bullet$ & $\bullet$ & $\bullet$ & $\mathrm{C}$ & $\bullet$ & $\bullet$ & $\bullet$ & $\bullet$ & $\bullet$ & $\mathrm{C}$ & $\mathrm{C}$ & $\bullet$ & $\mathrm{G}$ & $\mathrm{T}$ & $\mathrm{G}$ & $\bullet$ & $\bullet$ & $\mathrm{C}$ & $\bullet$ & $\bullet$ \\
$C h s-D$ & $\bullet$ & $\bullet$ & $\bullet$ & $\bullet$ & $\bullet$ & $\bullet$ & $\bullet$ & $\bullet$ & $\bullet$ & $\bullet$ & $\mathrm{C}$ & $\bullet$ & $\bullet$ & $\bullet$ & $\bullet$ & $\bullet$ & $\bullet$ & $\bullet$ & $\bullet$ & $\bullet$ & $\bullet$ & $\bullet$ \\
$C h s-F$ & $\bullet$ & $\bullet$ & $\bullet$ & $\bullet$ & $\mathrm{C}$ & $\bullet$ & $\bullet$ & $\mathrm{T}$ & $\bullet$ & $\bullet$ & $\bullet$ & $\bullet$ & $\bullet$ & $\mathrm{A}$ & $\bullet$ & $\bullet$ & $\bullet$ & $\bullet$ & $\bullet$ & $\bullet$ & $\bullet$ & $\bullet$ \\
$C h s-G$ & $\mathrm{C}$ & $\bullet$ & $\bullet$ & $\bullet$ & $\bullet$ & $\bullet$ & $\bullet$ & $\mathrm{T}$ & $\bullet$ & $\bullet$ & $\bullet$ & $\bullet$ & $\bullet$ & $\mathrm{A}$ & $\bullet$ & $\bullet$ & $\bullet$ & $\bullet$ & $\bullet$ & $\bullet$ & $\bullet$ & $\bullet$ \\
$C H S J-\mathrm{R} 5$ & $\mathrm{~A}$ & $\mathrm{~A}$ & $\mathrm{G}$ & $\mathrm{A}$ & $\mathrm{A}$ & $\mathrm{G}$ & $\mathrm{C}$ & $\mathrm{T}$ & $\mathrm{T}$ & $\mathrm{A}$ & $\mathrm{G}$ & $\mathrm{T}$ & $\mathrm{G}$ & $\mathrm{A}$ & $\mathrm{G}$ & $\mathrm{C}$ & $\mathrm{T}$ & $\mathrm{G}$ & $\mathrm{G}$ & $\mathrm{T}$ & $\mathrm{A}$ & $\mathrm{G}$ \\
$C h s-J$ & $\bullet$ & $\bullet$ & $\bullet$ & $\bullet$ & $\bullet$ & $\bullet$ & $\bullet$ & $\bullet$ & $\bullet$ & $\bullet$ & $\bullet$ & $\bullet$ & $\bullet$ & $\bullet$ & $\bullet$ & $\bullet$ & $\bullet$ & $\bullet$ & $\bullet$ & $\bullet$ & $\bullet$ & $\bullet$ \\
$C h s-A$ & $\bullet$ & $\bullet$ & $\bullet$ & $\mathrm{T}$ & $\bullet$ & $\bullet$ & $\bullet$ & $\bullet$ & $\bullet$ & $\bullet$ & $\bullet$ & $\bullet$ & $\bullet$ & $\bullet$ & $\bullet$ & $\mathrm{T}$ & $\bullet$ & $\bullet$ & $\mathrm{A}$ & $\bullet$ & $\bullet$ & $\bullet$ \\
$C h s-B$ & $\bullet$ & $\bullet$ & $\bullet$ & $\mathrm{G}$ & $\bullet$ & $\bullet$ & $\bullet$ & $\bullet$ & $\bullet$ & $\bullet$ & $\mathrm{A}$ & $\mathrm{C}$ & $\bullet$ & $\mathrm{T}$ & $\bullet$ & $\mathrm{A}$ & $\bullet$ & $\bullet$ & $\bullet$ & $\mathrm{C}$ & $\bullet$ & $\mathrm{A}$ \\
$C h s-D$ & $\bullet$ & $\bullet$ & $\bullet$ & $\bullet$ & $\bullet$ & $\bullet$ & $\bullet$ & $\bullet$ & $\bullet$ & $\mathrm{G}$ & $\bullet$ & $\bullet$ & $\mathrm{A}$ & $\bullet$ & $\bullet$ & $\bullet$ & $\bullet$ & $\bullet$ & $\mathrm{A}$ & $\mathrm{A}$ & $\bullet$ & $\bullet$ \\
$C h s-F$ & $\bullet$ & $\bullet$ & $\bullet$ & $\bullet$ & $\bullet$ & $\bullet$ & $\bullet$ & $\bullet$ & $\bullet$ & $\bullet$ & $\bullet$ & $\bullet$ & $\bullet$ & $\bullet$ & $\bullet$ & $\bullet$ & $\bullet$ & $\bullet$ & $\bullet$ & $\bullet$ & $\bullet$ & $\mathrm{A}$ \\
$C h s-G$ & $\bullet$ & $\bullet$ & $\bullet$ & $\bullet$ & $\bullet$ & $\bullet$ & $\bullet$ & $\bullet$ & $\bullet$ & $\bullet$ & $\bullet$ & $\bullet$ & $\mathrm{A}$ & $\bullet$ & $\bullet$ & $\mathrm{T}$ & $\bullet$ & $\bullet$ & $\bullet$ & $\bullet$ & $\bullet$ & $\bullet$ \\
\hline
\end{tabular}

${ }^{z}$ The accession numbers of the Chs genes: X14597 (Chs-J), X14591 (Chs-A), X14592 (Chs-B), X14593 (Chs-D), X14594 (Chs-F), X14595 (Chs-G).
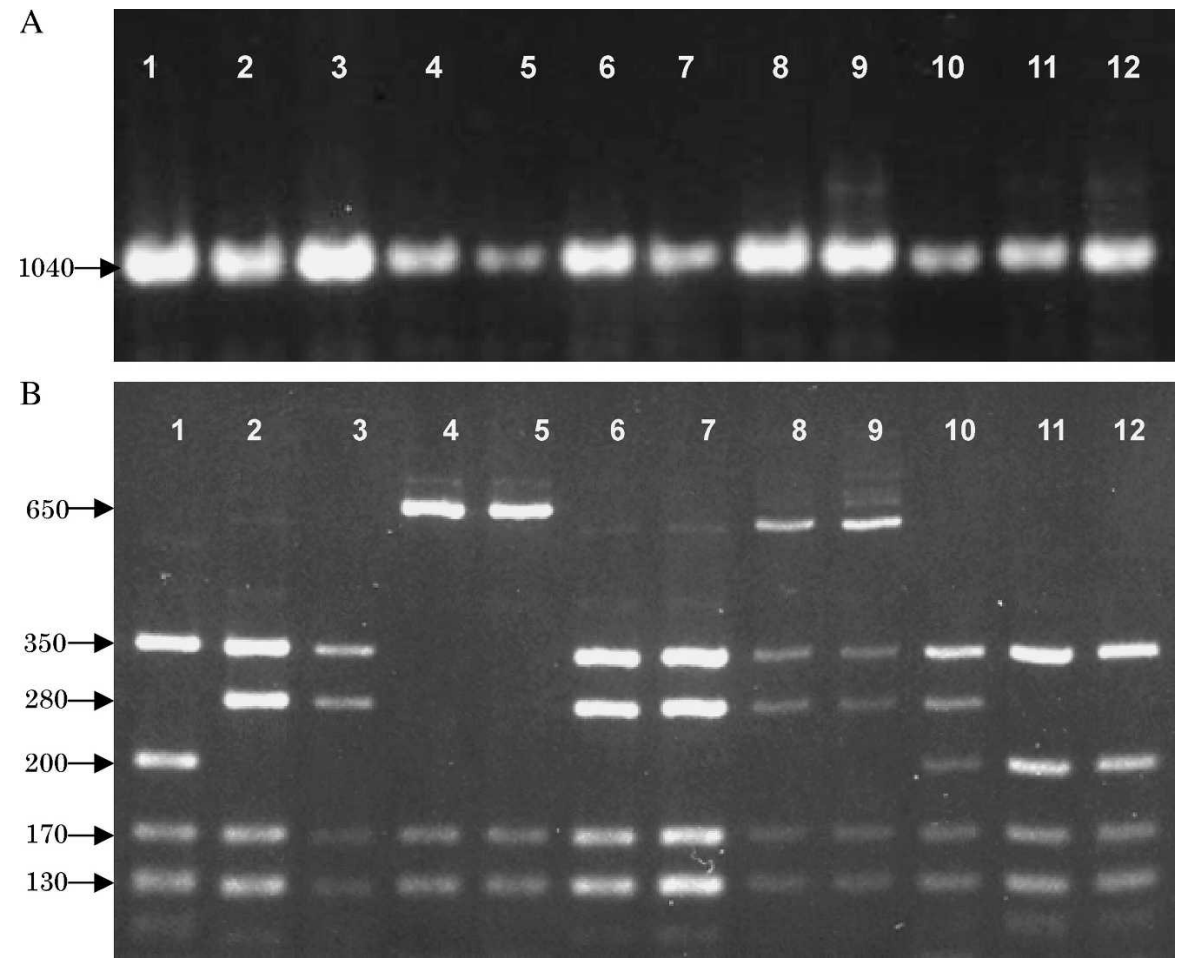

Fig. 2. Electrophoresis of (A) unrestricted polymerase chain reaction products and (B) their corresponding $R s a \mathrm{I}$ digestion products of $C h s-J$ intron. The sizes of the fragments (bases) are shown on the left. In both panels, lane $1 P$. axillaris subsp. axillaris, lane $2 P$. axillaris subsp. parodii, lane $3 P$. axillaris subsp. subandina, lane $4 P$. intergrifolia, lane 5 P. inflata, lane 6 P. hybrida 'Prime Time White', lane 7 P. hybrida 'Madness Pink', lane 8 P. hybrida 'Carpet Lilac', lane 9 P. hybrida 'Baccara Salmon', lane 10 P. hybrida 'Madness Orchid', lane 11 P. hybrida 'Flash Blue Vein', lane 12 P. hybrida 'Carpet Blue Lace'.

subsp. axillaris was found in the three garden petunias, 'Flash Blue Vein', 'Carpet Blue Lace', and 'Madness Orchid', suggesting that this subspecies had contributed to these garden petunias as one of the genetic donors. Likewise, coexistence of 350 and $280 \mathrm{bp} \mathrm{RsaI}$ restriction fragments found in $P$. axillaris subsp. parodii and subsp. subandina was detected in some garden petunias such as 'Prime Time White', 'Madness Pink', 'Carpet Lilac', 'Baccara Salmon', and 'Madness Orchid'. These facts also indicate that both or either one of $P$. axillaris subsp. parodii and subsp. subandina contributed to garden petunias as the genetic donors.
In the $P$. axillaris complex, three subspecies used in the present study are currently recognized to be distributed in different growing regions (Ando, 1996). Petunia axillaris subsp. axillaris was initially collected in Uruguay (Montevideo) by Philbert de Commerson, a French plant hunter, and described by Lamarck (1793). In contrast, other two subspecies, P. axillaris subsp. parodii and subsp. subandina, were described by Steere (1931) and Ando (1996), respectively. Because these two subspecies show the different distributions from $P$. axillaris subsp. axillaris in their natural habitat and advanced span, it might have no chance that they were introduced into Europe in the early 19th century. In the present study, it should be noted that specific fragments for subsp. subandina and subsp. parodii were found in garden petunias examined. Cerny et al. (1996) indicated that $P$. axillaris subsp. parodii is grouped into a cluster with some cultivars of garden petunias using molecular phylogeny analysis based on DNA amplification fingerprinting. Kokubun et al. (1997) reported that $P$. axillaris subsp. axillaris involved populations of the intermediate nature with subsp. parodii. Therefore, it is possible that such populations contributed as the progenitor of garden petunias. To verify the possibility, it is necessary to examine the presence of the specific fragments of $P$. axillaris subsp. subandina and subsp. parodii in such populations of subsp. axillaris and to develop subspecies-specific DNA markers of these taxa. More detailed PCR-RFLP analyses using more accessions are also needed.

Petunia integrifolia is presumed to be another progenitor of garden petunia, and $P$. inflata is a close relative of $P$. integrifolia. Both species showed a specific $650 \mathrm{bp} \mathrm{RsaI}$ restriction fragment, which is not found in all the subspecies of $P$. axillaris. In some garden petunias such as 'Carpet Lilac' and 'Baccara Salmon', the longest fragment detected was likely shorter than that $(650 \mathrm{bp})$ of $P$. integrifolia complex. After the introduction of $P$. integrifolia into England, artificial hybrids with $P$. axillaris were recorded and sold at almost every nursery around London (Paxton, 1836). Petunia inflata, because of the close similarity to $P$. integrifolia, is also suspected to have contributed as one of the parents (Sink, 1984). However, these two species are now regarded as allopatric species based on the significant morphological gaps and geographical distinctions (Ando et al., 2005 b). Therefore, it seems to be difficult to understand why the specific fragments for these two species are shorter in garden petunias examined in the present study. Although more detailed studies using many accessions and DNA markers is necessary for solving this puzzling problem, both or either one of these species might contribute to garden petunias as genetic donors.

\section{Conclusion}

Because garden petunia is a worldwide major horticultural plant, it is important and interesting to understand the breeding history of this important floricultural crop. In the present study, we successfully developed a PCR-RFLP analysis method based on the amplified region of Chs-J gene of Petunia, which enabled us to distinguish two presumed ancestral complex taxa, i.e., the $P$. axillaris complex and $P$. integrifolia complex. Moreover, $P$. axillaris subsp. axillaris could also be discriminated from the other two taxa, subsp. parodii and subsp. subandina within the $P$. axillaris complex, using this method, although it is still possible to find out some individuals with different PCRRFLP products in other populations for each 
subspecies. Although the contribution of these two complex taxa for the breeding of garden petunias was partially deduced in the present study, it is still difficult to identify the original taxa used for the initial breeding of garden petunias as the ancestral taxa. To clarify this puzzling problem, detailed studies will be needed to develop more molecular markers and to examine more accession of the wild taxa as well as diverged cultivars of garden petunias.

\section{Literature Cited}

Ando, T. 1996. Distribution of Petunia axillaris (Solanaceae) and its new subspecies in Argrentina and Bolivia. Acta Phytotax. Geobot. 47:19-30.

Ando, T., H. Kokubun, H. Watanabe, N. Tanaka, T. Yukawa, G. Hashimoto, E. Marchesi, E. Suarez, and I. Basuldo. 2005a. Phylogenetic analysis of Petunia sensu Jussieu (Solanaceae) using chloroplast DNA RFLP. Ann. Bot. (Lond.) 96:289-297.

Ando, T., N. Ihikawa, H. Watanabe, H. Kokubun, Y. Yanagisawa, G. Hashimoto, E. Marchesi, and E. Suarez. 2005b. A morphological study of the Petunia integrifolia complex (Solanaceae). Ann. Bot. (Lond.) 96:887-900.

Ando, T., N. Saito, F. Tatsuzawa, T. Kakefuda, K. Yamakage, E. Ohtani, M. Koshi-Ishi, Y. Matsusake, H. Kokubun, H. Watanabe, T. Tsukamoto, Y. Ueda, G. Hasimoto, E. Marchesi, K. Asakura, R. Hara, and H. Seki. 1999. Floral anthocyanins in wild taxa of Petunia (Solanaceae). Biochem. Syst. Ecol. 27:623-650.

Cerny, T.A., G. Caetano-Anolles, R.N. Trigiano, and T.W. Starman. 1996. Molecular phylogeny and DNA amplification fingerprinting of Petunia taxa. Theor. Appl. Genet. 92:1009-1016.
Ferguson, M.C. and A.M. Ottley. 1932. Studies in Petunia. III. A redescription and additional discussion of certain species of Petunia. Amer. J. Bot. 19:385-403.

Griesbach, R.J., R.M. Beck, and J.R. Stehmann. 2000. Molecular heterogeneity of the chalcone synthase intron in Petunia. HortScience 35: 1347-1349.

Heller, W. and K. Hahlbrock. 1980. Highly purified 'flavanone synthase' from parsley catalyzes the formation of naringenin chalcone. Arch. Biochem. Biophys. 200:617-619.

Kabbaj, A., F. Zeboudj, D. Peltier, A. Tagmount, M. Tersac, H. Dulieu, and A. Berville. 1995. Variation and phylogeny of the ribosomal DNA unit types and 5S DNA in Petunia Jussieu. Genetic Res. Crop Evol. 42:311-325.

Koes, R.E., C.E. Spelt, J.N.M. Mol, and A.G.M. Gerats. 1987. The chalcone synthase multigene family of Petunia hybrida (V30): Sequence homology, chromosomal localization and evolutionary aspects. Plant Mol. Biol. 10: 375-385.

Koes, R.E., C.E. Spelt, P.J.M. Van Den Elzen, and J.N.M. Mol. 1989a. Cloning and molecular characterization of the chalcone synthase multigene family of Petunia hybrida. Gene 81:245-257.

Koes, R.E., C.E. Spelt, and J.N.M. Mol. 1989b. The chalcone synthase multigene family of Petunia hybrida (V30): Differential, lightregulated expression during flower development and UV light induction. Plant Mol. Biol. 12: 213-225.

Kokubun, H., T. Ando, S. Kohyama, H. Watanabe, T. Tsukamoto, and E. Marchesi. 1997. Distribution of intermediate forms of $P$. axillaris subsp. axillaris and subsp. parodii (Solanaceae) in Uruguay as revealed by discriminant analysis. Acta Phytotax. Geobot. 48: 173-185.
Lamarck, J.B.P.A.M. 1793. Nicotiana axillaris. Tableau Encyclopedique et Method des Trois Regenes de la Nature, Botanique 2:7.

Lassner, M.W., P. Peterson, and J.I. Yoder. 1989. Simultaneous amplification of multiple DNA fragments by polymerase chain reaction in the analysis of transgenic plants and their progeny. Plant Mol. Biol. Rep. 7:116128.

Martsinkovskya, A.I., R.S. Moukhamedow, and A.A. Abdukarimov. 1996. Potential use of PCR-amplified ribosomal intergenic sequences for differentiation of varieties and species of Gossypium cotton. Plant Mol. Biol. Rep. 14:44-49.

Paxton, J. 1836. Petunia nyctaginiflora violacea. Paxton's Magazine of Botany 2:173.

Shen, Y., H.J. Newbury, and B.V. Ford-Lloyd. 1998. Identification of taxa in the genus Beta using ITS1 sequence information. Plant Mol. Biol. Rep. 16:147-155.

Sink, K.C. 1975. Inheritance of three genes for morphological characters in Petunia hybrida in crosses with four Petunia species. Canad. J. Genet. Cytol. 17:67-74.

Sink, K.C. 1984. Taxonomy, p. 3-9. In: K.C. Sink (ed.). Petunia. Springer, New York.

Steere, W.C. 1931. Petunia parodii, a new species of the subgenus Pseudonicotiana from Argentina. Papers of the Michigan Academy of Science, Arts and Letters 13:213-215.

Xu, D.H., J. Abe, A. Kanazawa, J.Y. Gai, and Y. Shimamoto. 2001. Identification of sequence variation by PCR-RFLP and its application to the evaluation of cpDNA diversity in wild and cultivated soybeans. Theor. Appl. Genet. 102:683-688.

Wijsman, H.J.W. 1982. On the inter-relationship of certain species of Petunia I. Taxonomic notes on the parental species of Petunia hybrida. Acta Bot. Neerl. 31:477-490. 